\title{
PILOCYTIC ASTROCYTOMA FOLLOWING RADIOTHERAPY FOR CRANIOPHARYNGIOMA
}

\author{
CASE REPORT
}

\author{
LEONARDO BONILHA*, GUILHERME BORGES **, YVENS B. FERNANDES ***, \\ RICARDO RAMINA***, EDMUR F CARELLI**, MARCELO ALVARENGA****
}

\begin{abstract}
Administration of fractionated doses of irradiation is part of the adjutant therapy for CNS tumours such as craniopharyngiomas and pituitary adenomas. It can maximise cure rates or expand symptom-free period. Among the adverse effects of radiotherapy, the induction of a new tumour within the irradiated field has been frequently described. The precise clinical features that correlate irradiation and oncogenesis are not completely defined, but some authors have suggested that tumors are radiation induced when they are histologically different from the treated ones, arise in greater frequency in irradiated patients than among normal population and tend to occur in younger people with an unusual aggressiveness. In this article, we report a case of a papillary astrocytoma arising in a rather unusual latency period following radiotherapy for craniopharyngioma.
\end{abstract}

KEY WORDS: pilocytic astrocytoma, radiotherapy adverse-effects, oncogenesis.

\section{Astrocitoma pilocítico pós-radioterapia para tratamento de craniofaringioma: relato de caso}

RESUMO - A administração de doses fracionadas de radiação é parte do tratamento adjuvante de tumores do sistema nervoso central como craniofaringiomas ou adenomas hipofisários. A radioterapia pode aumentar as chances de cura ou expandir o período livre de sintomas. Dentre seus efeitos adversos, é conhecida a possibilidade de aparecimento de novo tumor na região irradiada. Os critérios que definem se um novo tumor é de fato induzido por radiação ainda não são completamente definidos. Adimite-se, no entanto, que se o novo tumor é histologicamente diferente do primeiro, aparece em indivíduos mais jovens e é mais agressivo que o habitual, provavelmente sua origem é devida à oncogênese da irradiação. Descrevemos um caso de astrocitoma pilocítico possivelmente induzido por radioterapia, com surgimento em tempo de latência inesperadamente curto.

PALAVRAS-CHAVE: astrocitoma pilocítico, efeitos adversos de radioterapia, oncogênese.

Conventional radiation therapy is commonly applied as adjutant treatment for central nervous system (CNS) tumours ${ }^{1}$. Lesions that continue to growth despite surgical ablation or are not amenable to complete resection tend to recur lately when submitted to irradiation ${ }^{2}$. Among benign CNS tumours, pituitary adenomas and craniopharyngiomas are those for which standard fractionated radiation or stereotatic radiosurgery is usually performed ${ }^{3}$. For these lesions adjunctive radiation has a clear-cut positive effect maximising cure rates and adjourning the reappearance of symptoms. Radiation therapy can produce side effects such as tissue damage ${ }^{4-11}$ and neoplastic transformation ${ }^{1,12}$ in the irradiated field. Tumour development after radiotherapy is constantly described as an unusual but invariably serious medium term complication of irradiation ${ }^{13,14}$. For patients undergoing sellar irradiation, gliomas are the most frequent tumours, usually presented with marked aggressive behaviour and young age of onset ${ }^{1,11}$.

Faculdade de Ciências Médicas da Universidade de Campinas (UNICAMP). Disciplina de Neurocirurgia e Departamento de Radiologia: *Médico Residente - Disciplina de Neurocirurgia; **Professor Doutor - Disciplina de Neurocirurgia; ***Médico Contratado - Disciplina de Neurocirurgia, ****Professor Doutor - Departamento de Radiologia. Aceite: 27-abril-2000. 
In this article we report a case of radiation induced pilocytic astrocytoma with clinical aggressive behaviour developed in a rather unusual period (6 months) after radiotherapy for a craniopharyngioma.

\section{CASE}

A 36-year-old previously healthy woman was referred in 1996 to a neurosurgical consult by her endocrinologist with a 18-month history of symptoms of panhypopytuitarism and amenorrhoea. A skull roentgen showed a normal sellar region, while an MRI depicted a cystic supraselar lesion. In July of 1996, the patient underwent a right temporo-fronto-sphenoidal craniotomy with complete resection of the tumour. A histological examination of the specimen showed a suprasellar papillary squamous epithelium (Fig 1). The definitive diagnosis was papillary craniopharyngioma due to the complexity of the epithelium and the absence of skin adnexae and keratin, expected in dermoid and epidermoid cysts. One month after surgery the patient started radiation therapy with 5860cGy, with daily fractions of $180 \mathrm{cGy}$. Six months after the beginning of radiotherapy, the patient presented a progressive bitemporal hemianopia and a new MRI presented a $1.0 \times 0.9 \mathrm{~cm}$ supra sellar lesion infiltrating the optic chiasm. In June of 1997 the patient underwent a new surgical procedure with partial tumour resection. Histological analysis showed a lesion with conspicuous elongated and citologically bland cells intermixed with Rosenthal fibers (Fig 2). Due to its marked cellularity and the presence of the Rosenthal fibers, pylocitic astrocytoma was the definitive diagnosis, opposed to gliosis. The patient quickly developed complete blindness and diabetes insipidus after surgery and died 5 months later, reinforcing the diagnosis of a second tumour.

\section{DISCUSSION}

Tissue damage in the irradiated field yield side effects that in the brain and CNS may include optic neuritis $\mathrm{s}^{7,10}$, vasculopathy ${ }^{6,11}$, cognitive and psychological disturbances ${ }^{4,8}$ and hypothalamic insufficiency ${ }^{5,9}$. Moreover, due to base pair disruption and deoxyribonucleic acid (DNA) strand alteration, irradiation can produce neoplastic transformation ${ }^{12}$. Tumour development within the irradiated field constitutes a known consequence with very detrimental outcome ${ }^{13,14}$.

The most common intracranial nonglial CNS tumours induced by radiation are meningiomas and sarcomas ${ }^{12,15-17}$. After sellar irradiation gliomas are the most frequent glial tumours ${ }^{11,18}$. For patients undergoing sellar irradiation, the relative risk for developing a glioma is approximately 8 bigger

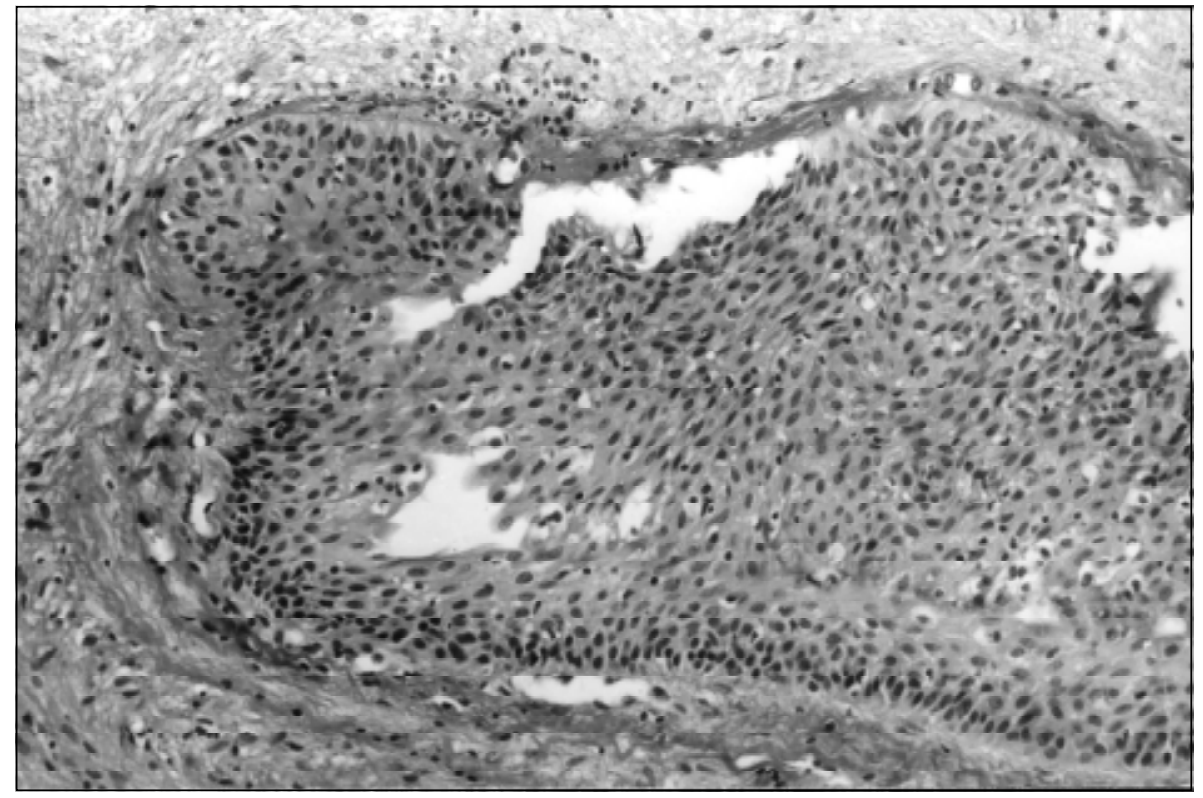

Fig 1. Cystic craniopharyngioma: rounded complex squamous epithelium with loose center. H\&E., 400x. 


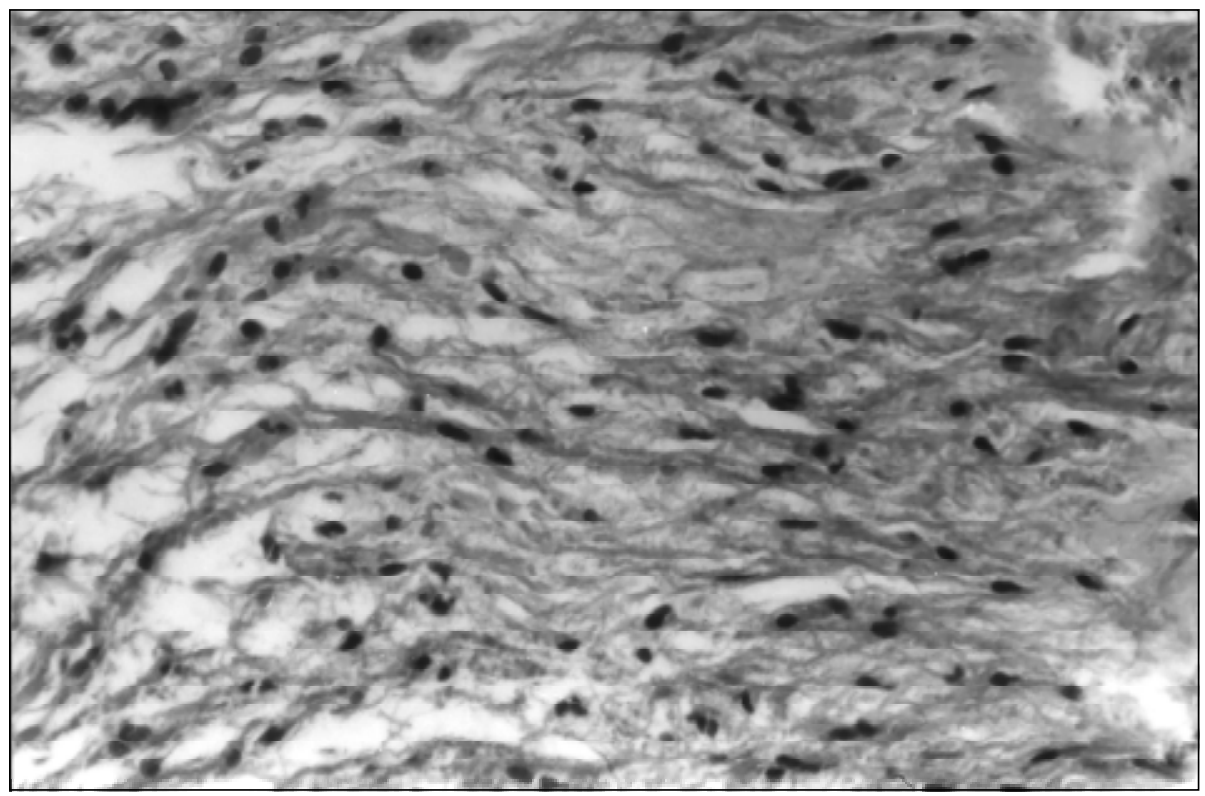

Fig 2. Pilocytic astrocytoma with astrocytes showing elongated nuclei and fibrillary cytoplasm, intermixed with Rosenthal fibers. $H \& E$., $400 x$.

than in the normal ${ }^{19}$. Tumour development after radiotherapy is considered radiation induced when some criteria are met. These include: the new lesion arises within the field of radiation; it is histologically different from the first tumour; it appears after a latency period that reasonably permits a secondary tumour development and there are not other conditions predisposing tumorigenesis ${ }^{20}$.

Tumours evolving after sellar irradiation are generally reported by sporadical case descriptions ${ }^{11}$. Despite the relative abundance of tumour neogenesis examples, the appearance of a second and unrelated CNS neoplasm after brain irradiation for a primary lesion is not the rule. However, the increased risk of developing a new tumour after irradiation and the peculiar settings presented by these second lesions argue against a simple coincident association ${ }^{21,22}$. In a cohort study performed in 1992 with 334 patients undergoing $4500 \mathrm{cGy}$ sellar irradiation for treatment of pituitary lesions, the relative risk of a new tumour development was significantly increased (7.92 times) compared to the one bore by the normal non-irradiated population ${ }^{19}$. Large series have shown that skull low dose irradiation (350-425cGy) for pediatric treatment of Tinea capitis increases the relative risk for developing a brain tumour by 2.6 times $^{18}$. Likewise, malignant CNS tumours have been witnessed to evolve in animal models submitted to brain irradiation with proton or x-ray in a much higher frequency than in non-irradiated animals ${ }^{13,23-25}$.

The use of fractionated doses of radiotherapy associated with spatial strategies to avoid excessive exposure of single brain territories or paths have been applied in order to minimise side effects and neoplastic transformation originated by radiation ${ }^{7,26}$. It is not yet known whether a clearcut dose response curve may be used regarding new tumour developing, but it seems that fractionated radiation is responsible to lessen the appearance of side effects ${ }^{7,27}$. The use of 50 to $55 \mathrm{cGy}$ in 25 sessions is capable of controlling primary tumour growth with a somewhat small level of complications $^{11,12,28}$.

Tumours appearing after irradiation usually differ from their "spontaneous" counterparts mainly because of the age of onset and aggressiveness observed ${ }^{21,22}$. The average range for glioma appearance in the normal population is the sixth decade. Gliomas appearing before or in the lower extreme of this range are generally expected to have a benign course. 
Table. Review of case reports of glioma after radiotherapy for craniopharyngiomas:

\begin{tabular}{lcccc}
\hline Reference & Age of diagnosis & Radiation dose & Latency period & $\begin{array}{c}\text { Glioma type } \\
\text { (WHO*) }\end{array}$ \\
\hline Ushio et al.. $(1997)^{29}$ & 6 years & $5460 \mathrm{cGy}$ & 5 years & IV \\
Sogg et al. $(1978)^{30}$ & 9 years & $6007 \mathrm{cGy}$ & 6 years & IV \\
Komaki et al. $(1977)^{31}$ & 22 years & $5400 \mathrm{cGy}$ & 6 years & IV \\
Gutjahr et al. $(1979)^{32}$ & 4 years & $6000 \mathrm{cGy}$ & 8 years & IV \\
Maat-Schieman et al. $(1985)^{33}$ & 5 years & $6000 \mathrm{cGy}$ & 14 years & III \\
Shimizu et al. $(1994)^{22}$ & 20 years & $6000 \mathrm{cGy}$ & 16 years & III \\
Kitanaka et al. $(1989)^{21}$ & 7 years & $6000 \mathrm{cGy}$ & 17 years & III \\
Liwnicz et al. $(1985)^{34}$ & 11 years & $5900 \mathrm{cGy}$ & 25 years & IV \\
\hline
\end{tabular}

*WHO, World Health Organization.

Comprehensive analysis of new cases of glioma after radiation for craniopharyngioma depict that its average age of onset is roughly $27 \mathrm{yr}$., much younger than the age of onset of glial tumours in the normal population or even after radiotherapy for pituitary adenomas, what is explained by the younger presentation of craniopharyngiomas ${ }^{1}$. Opposed to what should be expected in young patients also shows a rather different histological behaviour, with increased frequency of more aggressive patterns, comprising mainly grade III and IV gliomas.

We observed that in 8 cases of gliomas after radiotherapy for craniopharyngiomas (Table), the average latency period between irradiation and symptoms due to new tumour was $12.1 \mathrm{yr}$., with the smallest latency period reported of 5 years .

\section{Conclusion}

In this article we report an unusual case with unfavourable clinical outcome of a patient with craniopharyngioma who underwent surgical and irradiation treatment. As confirmed by post-surgical histological analysis, there was not recurrence of the first tumour but appearance of what could have been considered post-surgical gliosis or another tumour ${ }^{35}$. Since the patient was submitted to radiation therapy and had a fast unfavourable clinical course, we accepted that it was indeed a totally new lesion with very aggressive behaviour. We also considered that the histological feature of the second lesion was apparently benign, corresponding to a low-grade glioma. However, due to the rapid clinical deterioration, we considered it to be in fact a dynamic and rapid changing tumour, evolving quickly to aggressiveness. This hypothesis, unfortunately, could not have been confirmed by autopsy, which was not desired by the patient's relatives. Nonetheless, the data presented above strong suggests that the new lesion had a very aggressive and rapid changing status, based upon clinical settings.

The new tumour reported fulfils every variable suggested by the criteria above in order to be considered induced by radiation. However, it arised in a rather unusual latency period after radiotherapy (6 months). We therefore want to draw attention to irradiated induced tumours that may be formed in different settings, considering that it could have been originated by radiation, despite its rapid appearance.

\section{REFERENCES}

1. Simmons NE, Laws ER. Glioma ocurrence after sellar irradiation: case report and review. Neurosurgery 1998;42:172-178.

2. Inoue HK, Kohga H, Kakegawa T, et al.. Radiosensitive craniopharyngiomas: the role of radiosurgery. Acta Neurochir (Wien) 1994;62:43-46.

3. Tarbell NJ, Barnes P, Scott RM, et al.. Advances in radiation therapy for craniopharyngiomas. Pediatr Neurosurg 1994;21:101-107. 
4. Al-Meffy O, Kersh JE, Routh A, Smith RR. The long term side effects of radiation therapy for benign brain tumors in adults. J Neurosurg 1990;73:502-512.

5. Degerblad M, Rahn T, Bergstrand G, Thoren M. Long-term results of stereotatic radiosurgery to the pituitary gland in Cushing's disease. Acta Endocrinol (Copenh) 1986;112:310-314.

6. Gratten-Smith PJ, Morris JG, Langlands AO. Delayed radiation necrosis of the central nervous system in patients irradiated for pituitary tumors. J Neurol Neurosurg Psychiatry 1992;55:949-955.

7. Halberg FE, Sheline GE. Radiation for pituitary tumors. Endocrinol Metab Clin N Am 1987;16:667-684.

8. Jones A. Radiation oncogenesis in relation to the treatment of pituitary tumors. Clin Endocrinol (Oxf) 1991;35:379-397.

9. Knosp E, Perneczky A, Kitz K, Grunert P, Wild A. The need for adjuntive focused radiation therapy in pituitary adenomas. Acta Neurochir (Wien) 1995;63:81-84.

10. Kobaiashi T, Tanaka T, Kida Y. Stereotatic gamma radiosurgery for craniopharyngiomas. Pediatr Neurosurg 1994;21:69-74.

11. Pollock BE, Kondziolka D, Lunsford LD, Flickinger JC. Stereotatic radiosurgery for pituitary adenomas: imaging, visual and endocrine results. Acta Neurochir (Wien) 1994;62:33-38.

12. Harrison MJ, Wolfe DE, Lau T, Mitnick RJ, Sachdev VD. Radiation induced meningiomas: experience at the Mount Sinai Hospital and review of the literature. J Neurosurg 1991;75:564-574.

13. Kumar PP, Good RR, Skultety FM, Leibrock LG, Severson GS. Radiation induced neoplasms of the brain. Cancer 1987;59:1274-1282.

14. Piatt JH Jr, Blue JM, Schold SC, Burger PC. Glioblastoma multiforme after radiotherapy for acromegaly. Neurosurgery 1983;13-85-89.

15. Averback P. Mixed intracranial sarcomas: rare froms of and a new association with previous radiation-therapy. Ann Neurol 1978;4:229-233.

16. Musa BS, Pople IK, Cummins BH. Intracranial meningiomas following irradiation: a growing problem? Br J Neurosurg 1995;9:629-637.

17. Rubinstein AB, Shalit MN, Cohen ML, Zandbank U, Reichenthal E. Radiation-induced cerebral maningiomas: a recognizable entity. J Neurosurg 1984;61:966-971

18. Ron E, Modan B, Boice PH Jr, et al.. Tumors of the brain and nervous system after radiotherapy in childhood. N Eng J Med 1988;319:1033-1039

19. Brada M, Ford D, Ashley S, et al.. Risk of second brain tumor after conservative radiotherapy for pituitary adenoma. Br Med J 1992;304:1343-1346.

20. Cahan WG, Woodard HQ, Higinbothan NL, Stewart FW, Coley BL. Sarcoma arising in irradiated bone: report of eleven cases. Cancer 1948;1:3-29

21. Kitanaka C, Shitara N, Nakagomi T, et al.. Postradiation astrocytoma: report of two cases. J Neurosurg 1989;70:469-474.

22. Shimizu H, Fujiwara K, Kobaiashi S, Kitahara M. A case of paraventricular anaplastic astrocytoma following radiation therapy for craniopharyngioma. No Shinkei Geka 1994;22:357-352.

23. Traynor JE, Casey HM. Five-year follow-up of primates exposed to 55 Mev protons. Rad Res 1971;47:143-148.

24. Kent SP, Pickering JE. Neoplasms in monkeys (Macaca mullata): spontaneous and radiation-induced. Cancer 1958;11:138-147.

25. Haymaker W, Rubinstein LJ, Miquel J. Brain tumors in irradiated monkeys. Acta Neuropath (Berl) 1972;20:267-277.

26. Sohn JW, Dalzell JG, Suh JH, Tefft M, Schell MC. Dose-volume histogram analysis of technique for irradiation pituitary adenomas. Int J Radiat Oncol Biol Phys 1995;32:831-837.

27. Wen B, Hussey DH, Staples J, et al.. A comparison of the roles of surgery and radiation therapy in the management of craniopharyngiomas. Int J Radiol Oncol Biol Phys 1989;16:17-24.

28. McCollough WM, Marcus RB Jr, Rhoton AL Jr, Ballinger WE, Million RR. Long-term follow-up of radiotherapy for pituitary adenoma: the absence of late recurrence after ${ }^{3} 4500$ cGy. Int J Radiat Oncol Biol Phys 1991;21:607-614.

29. Ushio Y,Arita N, Yoshimine T, Nagatani M, Mogami H. Glioblastoma after radiotherapy for craniopharyngioma. Neurosurgery 1987;21:33-38

30. Sogg RL, Donaldson SS, Yorke CH. Malignant astrocytoma following radiotherapy of a craniopharyngioma. J Neurosurg 1978;48:622-627

31. Komaki S, Komaki R, Choi H, Correa-Paz F. Radiation and drug induced intracranial neoplasm with angiographic demonstration. Neurol Med Chir (Tokyo) 1977;17:55-62

32. Gutjahr P, Dieterich E. Risk of a second malignant neoplasm after successful treatment of a malignant tumour in children. Dtsch Med Wochenschr 1979;104:969-972

33. Maat-Schieman MLC, Bots GTAM, Thomeer TWM, Vielvoye GJ. Malignant astrocytoma following radiotherapy for craniopharyngioma. Br J Radiol 1985;58:480-482

34. Liwnicz BH, Berger TS, Liwnicz RG, Aron BS. Radiation-association gliomas: a report of four cases and analysis of postradiation tumors of the central nervous system. Neurosurgery 1985;17:436-445

35. Tolnay M, Kaim A, Probst A, Ulrich J. Subependymoma of the third ventricle after partial resection of a craniopharyngioma and repeated postoperative irradiation. Clin Neuropathol 1996;15:63-66. 